\title{
STATIN USE AND RISK OF NEW-ONSET DIABETES: A META-ANALYSIS OF OBSERVATIONAL STUDIES
}

\author{
STATIN-ASSOCIATED DIABETES RISK: META-ANALYSIS
}

\section{AUTHORS}

Casula $M^{a}(P h D)$, Mozzanica $F^{a}(P h a r m D)$, Scotti $L^{b}(P h D)$, Tragni $E^{a}(P h D)$, Pirillo $A^{c}(P h D)$, Corrao $G^{b}$ (Professor), Catapano $\mathrm{AL}^{\mathrm{a}, \mathrm{d}}$ (Professor)

\section{AFFILIATION}

a Epidemiology and Preventive Pharmacology Centre (SEFAP), Department of Pharmacological and Biomolecular Sciences, University of Milan, via Balzaretti 9, 20133 Milan, Italy

b Department of Statistics and Quantitative Methods, Division of Biostatistics, Epidemiology and Public Health, University of Milano-Bicocca, Via Bicocca degli Arcimboldi 8, 20126 Milan, Italy

c Center for the Study of Atherosclerosis, E. Bassini Hospital, Via M. Gorki 50, Cinisello Balsamo, 20092 Milan, Italy d IRCCS MultiMedica, via Milanese 300, 20099 Sesto S. Giovanni (MI), Italy

\section{CORRESPONDENCE}

\section{Manuela Casula}

Epidemiology and Preventive Pharmacology Centre (SEFAP), Department of Pharmacological and Biomolecular Sciences, University of Milan, Via Balzaretti 9, 20133 Milan, Italy.

Tel +3902503 18428. Fax +390250318386

E-mail: sefap@unimi.it

Word count 2908

N Figures 3

$\mathrm{N}$ tables 2 


\section{ABSTRACT}

BACKGROUND AND AIMS Meta-analyses of randomized control trials investigating the association between incident diabetes and statin use showed an increased risk of new-onset diabetes (NOD) from $9 \%$ to $13 \%$ associated with statins. However, short follow-up period, unpowered sample size, and lack of pre-specified diagnostic criteria for diabetes detection could be responsible of an underestimation of this risk. We conducted a meta-analysis of published observational studies to evaluate the association between statins use and risk of NOD.

METHODS AND RESULTS PubMed, EMBASE and MEDLINE databases were searched from inception to June 30, 2016 for cohort and case-control studies with risk of NOD in users vs nonusers, on $\geq 1000$ subjects followed-up for $\geq 1$ year. Two review authors assessed study eligibility and risk of bias and undertook data extraction independently. Pooled estimates were calculated by a random-effects model and between-study heterogeneity was tested and measured by $\mathrm{I}^{2}$ index. Furthermore, stratified analyses and the evaluation of publication bias were performed. Finally, the meta-analysis included 20 studies, 18 cohort and 2 case-control studies. Overall, NOD risk were higher in statin users than nonusers (RR 1.44; 95\% Cl 1.31-1.58). High between-study heterogeneity $\left(\mathrm{I}^{2}=97 \%\right)$ was found. Estimates for all single statins showed a class effect, from rosuvastatin (RR $1.61 ; 1.30-1.98)$ to simvastatin (RR 1.38; 1.19-1.61).

CONCLUSIONS The present meta-analysis confirms and reinforces the evidence of a diabetogenic effect by statins utilization. These observations confirm the need of a rigorous monitoring of patients taking statins, in particular pre-diabetic patients or patients presenting with established risk factors for diabetes.

KEYWORDS: statins; incident diabetes; meta-analysis; observational studies 


\section{INTRODUCTION}

Statin therapy represents the basis for the management of hypercholesterolemia and prevention of cardiovascular disease [1, 2]. Statins are generally safe and well tolerated. However, some studies have reported an association between statin therapy and the risk of new-onset diabetes.

The first trial that evaluated the relationship between statin therapy and incident type 2 diabetes was the West of Scotland Coronary Prevention Study (WOSCOPS), which observed that pravastatin $40 \mathrm{mg} /$ day was associated with a $30 \%$ risk reduction for incident diabetes in a high-risk population of men with severe hypercholesterolemia [3]. Since then, several other studies have investigated this relationship, reporting controversial results. In fact, while some studies did not show any apparent effect of statins on the development of new diabetes [3-6], other investigations suggested an increased risk. Among these, the JUPITER (Justification for the Use of Statin in Prevention: an Intervention Trial Evaluating Rosuvastatin) trial, in which statin treatment was associated with small but significantly higher levels of glycated hemoglobin and incidence rates of diabetes [7], and an analysis of the WHI (Women's Health Initiative), which reported an increased risk of diabetes mellitus in postmenopausal women taking statins [8]. These findings, together with observations from other clinical trials [9], led to hypothesize that statin therapy might trigger mechanisms leading to the development of diabetes. Several meta-analyses have thus evaluated data from available trials to define whether statin therapy may have a role in the development of type 2 diabetes, and observed an excess risk ranging from $9 \%$ up to $13 \%$ [10-14]. In particular, the increased risk of incident diabetes seems to be associated with high-intensity statin therapy [13]. A recent meta-analysis [15] showed that statins, as a class, significantly increase the risk of new-onset diabetes by $12 \%$ and that atorvastatin $80 \mathrm{mg}$ was associated with the highest risk, followed by rosuvastatin, and simvastatin 80 mg; high dose atorvastatin increased the risk of diabetes even when compared with other statins such as pravastatin, simvastatin or low-dose atorvastatin, in agreement with previous findings.

Despite the risk of incident diabetes is low both in absolute and when compared with the significant reduction of cardiovascular events, the real weight of this risk is still undetermined. In 
addition, randomized clinical trials (RCTs) have several limitations that might reduce the actual relevance of such increased risk [16]. RCTs in fact, did not include diabetes risk as a primary outcome; as a consequence, they could not reach adequate statistical power and sample size to find an association between statin use and diabetes risk. In addition, the absence of pre-specified criteria for diabetes diagnosis and detection, together with selection bias and dropout from studies, may lead to an underestimation of adverse cases. Finally, the relatively short follow-up period typical of RCTs or the possibility to prematurely terminate the trial once benefits are documented may preclude the detection of a chronic condition such as diabetes [16]. On the other hands, observational studies can be very large and have unlimited duration and follow-up, thus increasing the chance to detect adverse events with low incidence. Aim of the present study was thus to investigate the relationship between statin therapy and risk of incident diabetes by undertaking a meta-analysis of all available observational studies.

\section{METHODS}

This study was designed according to the Preferred Reporting Items for Systematic Reviews and Meta- Analyses (PRISMA) and the Meta-analysis of Observational Studies in Epidemiology (MOOSE) guidelines [17, 18].

\section{Study selection criteria}

We evaluated observational studies that reported or allowed to calculate risk of new-onset diabetes (NOD) with statin use.

Studies were included if they met the following criteria: (1) the study examined risk of NOD for statin use vs non-use; (2) the study recruited 1000 participants or more; (3) follow-up was at least 1 year;

(4) the risk estimate was reported as an odds ratio $(O R)$, hazard ratio $(H R)$ or relative risk $(R R) ;(5)$ the $95 \% \mathrm{Cl}$ for the risk estimate was included. 


\section{Search strategy}

PubMed, MEDLINE, and EMBASE were searched from inception to 30 June 2016. The search strategy included keywords and $\mathrm{MeSH}$ terms relating to statins and type 2 diabetes.

The keywords included: "hydroxymethylglutaryl-CoA reductase inhibitors" or "statins", "diabetes", "cohort study" or "case-control study". One of the complete search strings is presented in Supplementals.

We excluded studies published as abstracts. The review was restricted to original articles published in English. We also manually searched bibliographies of included studies as well as existing systematic reviews for any other articles that may be potentially suitable.

\section{Data extraction and evaluation}

Two authors independently scanned all titles and abstracts and excluded articles that clearly were not observational studies on the topic. We proceeded to assess full-text versions of potentially relevant articles and conducted more detailed checks against our eligibility criteria. Disagreements were resolved by discussion.

We used preformatted tables (Table 1) to record study design and participant characteristics. Data extracted from observational studies were first author, year of publication, mean age range of participants, median follow-up time, drug exposure, and definition of NOD. We also extracted full adjusted estimates of risk along with $95 \%$ confidence intervals.

A quality assessment of included studies was conducted for descriptive purposes and to evaluate potential differences according to quality criteria (Supplemental data). Two authors independently assessed study quality and resolved disagreements by further review and discussion. The methodological quality of the included case-control and cohort studies was evaluated using the validated Newcastle-Ottawa scale [19]. Scores range from zero to 10 stars.

\section{Statistical analysis}


We pooled the estimates by using the fixed-effects and random-effects model according to DerSimonian \& Laird method [20]. When a significant heterogeneity was found, the results from the random-effects model were presented. Between-study heterogeneity was tested by Cochrane's $Q$ test and measured with the $\mathrm{I}^{2}$ statistic (the proportion of between-study variability caused by heterogeneity) [21]. A stratified analysis was performed to assess if follow-up length, geographic area and propensity score matching could be the source of between study heterogeneity.

Publication bias was evaluated visually through funnel plot and with the Egger's test [22].

To evaluate to what extent obtained results could be influenced by a single study, an influence analysis was performed by omitting one study at a time.

All tests were considered statistically significant for $p$-values less than 0.05 . The analyses and the corresponding graphical visualization of forest and funnel plots were conducting using $\mathrm{R}$ package "metafor" (v 1.9-7).

\section{RESULTS}

Overall, 2,272 unique papers were retrieved from PUBMED, EMBASE and MEDLINE databases. Based on title/abstract, we selected 43 studies for full-text evaluation; among them, 20 observational studies fulfilling inclusion criteria were included in the final analyses (Figure 1) [8, 16, 23-40].

Characteristics of the included studies are shown in table 1. The years of publication range from 2004 to June 2016; 2 of them were case-control studies [25, 35], 18 were cohort studies. The follow-up duration ranged between 2-20 years (median 7.2 years). Most of the studies were conducted in Europe (8 studies) and US (7 studies). The quality evaluation based on the Newcastle-Ottawa scale found an average score of 7 , with 9 studies having score $\geq 8$ (Supplemental Table 1).

Overall, statin users have significantly greater risk of new-onset diabetes compared with non-users (RR 1.44; 95\% Cl, 1.31-1.58) (Figure 2). When considering single statins, we observed that users of 
rosuvastatin and atorvastatin have the greatest increase in diabetes risk, being the relative risk 1.61 $(95 \% \mathrm{Cl}, 1.30-1.98)$ in rosuvastatin users and $1.49(95 \% \mathrm{Cl}, 1.31-1.70)$ in atorvastatin users (Figure 3). All reported estimates were obtained using the random-effect model since a large between-study heterogeneity was detected in all analyses (the $\mathrm{I}^{2}$ index was $97 \%$ for any statin).

\section{Stratified analysis}

Table 2 shows the results of the stratified analysis. Follow-up duration and propensity score matching do no seems to be sources of heterogeneity, since the between strata-specific estimates do not differ (p-values 0.173 and 0.195 respectively). On the contrary, an effect of the country was observed ( $p$ value $<0.001$ ), mainly due to the only study from New Zeland [26], which reported a higher association estimate compared with the other included studies; in fact, omitting this study, the test for the difference between group estimates provides a p-value of 0.197 .

\section{$\underline{\text { Publication bias }}$}

Evidence of publication bias was found for atorvastatin ( $p$-value Egger's test $=0.03$ ) but not for other statins or for use of any statin (Supplemental Figures 1 and 2).

\section{Influence analysis}

As reported above, the overall pooled estimate is $1.44(95 \% \mathrm{Cl}, 1.31-1.58)$; when we performed the influence analysis by omitting one study at a time, we did not observe any significant change in the estimate pooled, suggesting that none of the included studies affects substantially the overall estimate (Supplemental Table 3).

\section{DISCUSSION}


The results of our study show a $44 \%$ increased risk of new-onset diabetes among statin users compared with non-users; the analysis of single statins, indicating an increased risk varying from $38 \%$ in simvastatin users up to $61 \%$ in rosuvastatin users, suggesting a class effect. A high betweenstudy heterogeneity was observed in our meta-analysis; the influence analysis shows a slight (but not significant) impact of the study of Currie et al., [26] on the pooled estimate for overall statin use. Analyses of influence and publication bias, although showed some evidence that individual papers and selective inclusion might have some effect respectively, do not seem to materially affect our estimates.

Several clinical trials have reported an increased risk of new-onset diabetes in statin users, and meta-analyses of randomized clinical trials have confirmed such a finding [10-15]. In line with this, the present meta-analysis of available observational studies shows that subjects treated with statins are at higher risk of developing diabetes compared with patients not treated with statins. The increase of risk results much higher compared with previous meta-analyses of RCTs (44\% vs 9-13\%) [10, 11, 13, $14,41,42]$, probably due to the different characteristics of RCTs and observational studies.

Compared with RCTs, observational studies include, in fact, many more subjects followed for a longer time which may result in an increased chance to detect adverse events, in particular those that may require several years to occur or be detected, such as diabetes [16]. Furthermore, the rigorous selection of subjects recruited for an RCT may lead to the exclusion of individuals at higher risk for adverse events [16], and this may result in an underestimation of adverse events, in particular if their incidence is low. In addition, RCTs may have an early stop than planned due to exciding benefits, as they are designed and powered to detect efficacy, and this may further reduce the chance to detect adverse events.

On the other hand, despite more generalizable than RCTs, due to the lack of subject selection, observational studies may have some limitations. In fact, while in RCTs randomization leads to a comparable distribution of known and unknown factors potentially affecting any observable variable in the compared groups, this is not possible in observational studies due to the absence of randomization, and can result in biases. 
A major limitation in the interpretation of results from observational studies is the "indication bias"; in our case, patients treated with statins may be more prone to develop diabetes than those not exposed to statin therapies. Pre-diabetes, i.e. the most important risk factor for type 2 diabetes, is often associated with dyslipidaemia and this increases the chance that subjects with pre-diabetes will be treated with statins; moreover, statin-treated subjects tend to be sicker than non-statin users, and thus they may develop diabetes with higher frequency independently of statin use [43]. Investigators attempted to obtain comparable groups by a range of methods including nested sampling, controlling for potential confounders and propensity score matching. In some studies, risk estimates were adjusted for lipid levels [27, 34, 39] or propensity score was calculated for matching or adjustment purposes [8, 16, 25, 29, 30, 34, 36-39, 44]. For example, Jick et al. [35] limited the study population to untreated and statin treated hyperlipidaemics to minimize the effects of hyperlipidaemia itself on the development of diabetes. Also in the study by Corrao et al. [45], the risk of incident diabetes showed a continuous increasing trend with increasing levels of adherence, compared to dyslipidemic patients with low adherence, supporting the role of the drug, in addition to the underlying disease. This finding is further supported by several randomized clinical trials in which an increased diabetes risk among statin users was observed, and randomization is particularly efficient in controlling for selection bias and confounding.

Another potential bias in observational studies is the detection bias, which occurs when a phenomenon is more likely to be observed for a particular set of study subjects. In our case, we can speculate that people prescribed a therapy are more likely to be clinically evaluated, thus increasing their chance of being diagnosed with diabetes. Despite this, in the studies in which adjustment or stratification by frequency of cholesterol tests and outpatient visits was performed the increase in NOD risk was still present $[35,45,46]$. In addition, patients prescribed statins have a higher risk of new-onset diabetes compared with patients prescribed diclofenac, suggesting that in these two groups of patients, having the same chance to be clinically evaluated, the increased NOD risk can be attributed to statins [26]; moreover, when patients treated with statins were evaluated for the incidence of peptic ulcer, considered as a negative outcome control for statin treatment, a null 
association was observed, as expected, suggesting that the observed increase of NOD risk was not due to bias $[27,46]$

In our meta-analysis, we observed little publication bias for atorvastatin. In particular it seems that studies reporting a statistically significant increased risk of new-onset diabetes are more likely published. Since the effect of publication bias was detected exclusively for this statin, it is possible that the effect of atorvastatin may have been overestimated, but it is also reasonable that atorvastatin increases the NOD risk similarly to other statins.

Several studies were performed to identify the biological mechanisms explaining the diabetogenic effect of statins. As first, the inhibition of the statin target 3-hydroxy-methylglutaryl-CoA reductase (HMGCR) seems to play a role [47]. In fact, the analysis of the single nucleotide polymorphism (SNP) rs17238484 in the HMGCR gene showed that the rs17238484-G allele was associated with lower LDL-C levels, higher plasma levels of insulin and glucose, greater waist and hip circumference and increased body weight [47]; another SNP, rs12916, showed similar associations with these parameters [47]. Thus, both SNPs seem to be associated with increased risk of diabetes, independently of statin therapy use. In agreement with this observation, statin treatment in randomized trials is associated with bodyweight gain and increased risk of incident diabetes [47].

Besides, the LDL-C-lowering effect of statins may itself increase the risk of diabetes among statin users. In fact, low LDL-C levels are associated with an increased risk of developing new diabetes in subjects not treated with lipid-modifying therapies [48], and this finding is supported by several independent observations. As first, despite at clinical level dyslipidemia is associated with hyperglycemia and insulin resistance, the genetic predisposition to dyslipidemia is associated with lower levels of diabetes-related parameters, including fasting plasma glucose, glycated hemoglobin and HOMA-IR, suggesting pleiotropic effects of lipid genes on these parameters independent of blood lipid levels [49]. In addition, genetically higher circulating LDL-C levels are associated with a lower risk of diabetes, as shown by either the analysis of SNPs on genes related to lipid metabolism [50] or by the observation of a lower prevalence of type 2 diabetes among patients with familial 
hypercholesterolemia compared with unaffected relatives [51], as well as in FH patients with LDLR negative mutations compared with FH patients with LDLR defective mutations [51].

Other mechanisms may however contribute to the new-onset diabetes induced by statins [52]. Several in vitro studies suggest that statin treatment may be detrimental for pancreatic B-cell function. In fact, statins dose-dependently induce B-cell damage and smooth muscle cell insulin resistance [53], reduce glucose transporter 4 (GLUT4) expression, a transporter responsible for the uptake of glucose in peripheral cells [53-55], reduce insulin signal transduction [54, 56, 57], inhibit adipocyte differentiation, thus leading to accumulation of cells unable to secrete insulin-sensitizing hormone and to insulin resistance [54], and reduce pancreatic B-cell function [58-60]. By inhibiting the cholesterol synthesis pathway, statins also inhibit the synthesis of several other products that are relevant for normal cell functions, such as those involved in glucose homeostasis [52]. Additional mechanisms, such as the link between statin treatment and specific microRNAs involved in the reduction of insulin secretion, are currently being investigated [52].

In summary, our meta-analysis of observational studies confirms and reinforces the evidence that statins possess diabetogenic properties; all considered statins significantly increase the risk of incident diabetes, independently of their chemico-physical characteristics, suggesting thus a class effect. Some authors [61] tried to quantify the excess risk of cardiovascular events derived from the increased incidence of statins-associated diabetes, concluding with the confirmation of a favorable risk-benefit ratio of these drugs, due to the large reduction in cardiovascular risk. Although the estimates need to be updated with the higher risk from observational studies, we should consider that the diabetic patient is not only characterized by an increased cardiovascular risk, but also by other complications, the need for drugs, and worse quality of life. These aspects are difficult to quantify, but might result in a clinical and economic impact. These observations confirm the need of a rigorous monitoring of patients taking statins, in particular pre-diabetic patients or patients presenting with established risk factors for diabetes. 


\section{ACKNOWLEDGMENT}

MC, FM, and ALC were responsible for the study concept and design. MC and FM retrieved data. LS did the analysis. GC, ET, and ALC contributed to the data analysis and interpretation of the results. AP, MC and FM drafted the manuscript and all authors critically revised for important intellectual content and approved the final manuscript. Guarantor: ALC.

All authors declare: no support from any organisation for the submitted work; no financial relationships with any organisations that might have an interest in the submitted work in the previous three years; no other relationships or activities that could appear to have influenced the submitted work.

\section{FIGURE LEGENDS}

Figure 1 Flow-chart for the selection of eligible observational studies

Figure 2 Meta-analysis of risk of new onset diabetes for any statin use vs non use

Figure 3 Meta-analysis of risk of new onset diabetes for specific statin use vs non use

\section{REFERENCES}

[1] Cholesterol Treatment Trialists C, Fulcher J, O'Connell R, Voysey M, Emberson J, Blackwell L, et al. Efficacy and safety of LDL-lowering therapy among men and women: meta-analysis of individual data from 174,000 participants in 27 randomised trials. Lancet. 2015;385:1397-405.

[2] Cholesterol Treatment Trialists C, Baigent C, Blackwell L, Emberson J, Holland LE, Reith C, et al. Efficacy and safety of more intensive lowering of LDL cholesterol: a meta-analysis of data from 170,000 participants in 26 randomised trials. Lancet. 2010;376:1670-81.

[3] Freeman DJ, Norrie J, Sattar N, Neely RD, Cobbe SM, Ford I, et al. Pravastatin and the development of diabetes mellitus: evidence for a protective treatment effect in the West of Scotland Coronary Prevention Study. Circulation. 2001;103:357-62.

[4] Downs JR, Clearfield M, Weis S, Whitney E, Shapiro DR, Beere PA, et al. Primary prevention of acute coronary events with lovastatin in men and women with average cholesterol levels: results of AFCAPS/TexCAPS. Air Force/Texas Coronary Atherosclerosis Prevention Study. Jama. 1998;279:1615-22.

[5] Results of the low-dose $(20 \mathrm{mg}$ ) pravastatin GISSI Prevenzione trial in 4271 patients with recent myocardial infarction: do stopped trials contribute to overall knowledge? GISSI Prevenzione Investigators (Gruppo Italiano per lo Studio della Sopravvivenza nell'Infarto Miocardico). Italian heart journal : official journal of the Italian Federation of Cardiology. 2000;1:810-20. 
[6] Keech A, Colquhoun D, Best J, Kirby A, Simes RJ, Hunt D, et al. Secondary prevention of cardiovascular events with long-term pravastatin in patients with diabetes or impaired fasting glucose: results from the LIPID trial. Diabetes care. 2003;26:2713-21.

[7] Ridker PM, Danielson E, Fonseca FA, Genest J, Gotto AM, Jr., Kastelein JJ, et al. Rosuvastatin to prevent vascular events in men and women with elevated C-reactive protein. The New England journal of medicine. 2008;359:2195-207.

[8] Culver AL, Ockene IS, Balasubramanian R, Olendzki BC, Sepavich DM, Wactawski-Wende J, et al. Statin use and risk of diabetes mellitus in postmenopausal women in the Women's Health Initiative. Archives of internal medicine.

2012;172:144-52.

[9] Park ZH, Juska A, Dyakov D, Patel RV. Statin-associated incident diabetes: a literature review. The Consultant pharmacist : the journal of the American Society of Consultant Pharmacists. 2014;29:317-34.

[10] Rajpathak SN, Kumbhani DJ, Crandall J, Barzilai N, Alderman M, Ridker PM. Statin therapy and risk of developing type 2 diabetes: a meta-analysis. Diabetes care. 2009;32:1924-9.

[11] Sattar N, Preiss D, Murray HM, Welsh P, Buckley BM, de Craen AJ, et al. Statins and risk of incident diabetes: a collaborative meta-analysis of randomised statin trials. Lancet. 2010;375:735-42.

[12] Mills EJ, Wu P, Chong G, Ghement I, Singh S, Akl EA, et al. Efficacy and safety of statin treatment for cardiovascular disease: a network meta-analysis of 170,255 patients from 76 randomized trials. QJM : monthly journal of the Association of Physicians. 2011;104:109-24.

[13] Preiss D, Seshasai SR, Welsh P, Murphy SA, Ho JE, Waters DD, et al. Risk of incident diabetes with intensive-dose compared with moderate-dose statin therapy: a meta-analysis. Jama. 2011;305:2556-64.

[14] Cai R, Yuan Y, Zhou Y, Xia W, Wang P, Sun H, et al. Lower intensified target LDL-c level of statin therapy results in a higher risk of incident diabetes: a meta-analysis. PloS one. 2014;9:e104922.

[15] Thakker D, Nair S, Pagada A, Jamdade V, Malik A. Statin use and the risk of developing diabetes: a network metaanalysis. Pharmacoepidemiology and drug safety. 2016.

[16] Mansi I, Frei CR, Wang CP, Mortensen EM. Statins and New-Onset Diabetes Mellitus and Diabetic Complications: A Retrospective Cohort Study of US Healthy Adults. Journal of general internal medicine. 2015;30:1599-610.

[17] Moher D, Shamseer L, Clarke M, Ghersi D, Liberati A, Petticrew M, et al. Preferred reporting items for systematic review and meta-analysis protocols (PRISMA-P) 2015 statement. Systematic reviews. 2015;4:1.

[18] Stroup DF, Berlin JA, Morton SC, Olkin I, Williamson GD, Rennie D, et al. Meta-analysis of observational studies in epidemiology: a proposal for reporting. Meta-analysis Of Observational Studies in Epidemiology (MOOSE) group. Jama. 2000;283:2008-12.

[19] Wells GA, Shea B, O'Connell D, Peterson J, Welch V, Losos M, et al. The Newcastle-Ottawa Scale (NOS) for assessing the quality if nonrandomized studies in meta-analyses. .

[20] DerSimonian R, Laird N. Meta-analysis in clinical trials. Control Clin Trials. 1986;7:177-88.

[21] Higgins JP, Thompson SG, Deeks JJ, Altman DG. Measuring inconsistency in meta-analyses. Bmj. 2003;327:557-60.

[22] Egger M, Davey Smith G, Schneider M, Minder C. Bias in meta-analysis detected by a simple, graphical test. Bmj. 1997;315:629-34.

[23] Bhattacharya R, Ajmera M, Bhattacharjee S, Sambamoorthi U. Use of antidepressants and statins and short-term risk of new-onset diabetes among high risk adults. Diabetes research and clinical practice. 2014;105:251-60.

[24] Cederberg H, Stancakova A, Yaluri N, Modi S, Kuusisto J, Laakso M. Increased risk of diabetes with statin treatment is associated with impaired insulin sensitivity and insulin secretion: a 6 year follow-up study of the METSIM cohort. Diabetologia. 2015;58:1109-17.

[25] Chen CW, Chen TC, Huang KY, Chou P, Chen PF, Lee CC. Differential impact of statin on new-onset diabetes in different age groups: a population-based case-control study in women from an asian country. PloS one. 2013;8:e71817. [26] Currie O, Mangin D, Williman J, McKinnon-Gee B, Bridgford P. The comparative risk of new-onset diabetes after prescription of drugs for cardiovascular risk prevention in primary care: a national cohort study. BMJ open.

2013;3:e003475.

[27] Danaei G, Garcia Rodriguez LA, Fernandez Cantero O, Hernan MA. Statins and risk of diabetes: an analysis of electronic medical records to evaluate possible bias due to differential survival. Diabetes care. 2013;36:1236-40. [28] Izzo R, de Simone G, Trimarco V, Giudice R, De Marco M, Di Renzo G, et al. Primary prevention with statins and incident diabetes in hypertensive patients at high cardiovascular risk. Nutrition, metabolism, and cardiovascular diseases : NMCD. 2013;23:1101-6.

[29] Lichtenstein KA, Hart RL, Wood KC, Bozzette S, Buchacz K, Brooks JT, et al. Statin Use Is Associated With Incident Diabetes Mellitus Among Patients in the HIV Outpatient Study. Journal of acquired immune deficiency syndromes. 2015;69:306-11.

[30] Macedo AF, Douglas I, Smeeth L, Forbes H, Ebrahim S. Statins and the risk of type 2 diabetes mellitus: cohort study using the UK clinical practice pesearch datalink. BMC cardiovascular disorders. 2014;14:85. 
[31] Radford NB, DeFina LF, Barlow CE, Kerr A, Chakravorty R, Khera A, et al. Effect of fitness on incident diabetes from statin use in primary prevention. Atherosclerosis. 2015;239:43-9.

[32] Zaharan NL, Williams D, Bennett K. Statins and risk of treated incident diabetes in a primary care population. British journal of clinical pharmacology. 2013;75:1118-24.

[33] Calza L, Colangeli V, Magistrelli E, Manfredi R, Bon I, Re MC, et al. No correlation between statin exposure and incident diabetes mellitus in HIV-1-infected patients receiving combination antiretroviral therapy. HIV medicine. 2016. [34] Castro MR, Simon G, Cha SS, Yawn BP, Melton L, 3rd, Caraballo PJ. Statin Use, Diabetes Incidence and Overall Mortality in Normoglycemic and Impaired Fasting Glucose Patients. Journal of general internal medicine. 2016;31:502-8. [35] Jick SS, Bradbury BD. Statins and newly diagnosed diabetes. British journal of clinical pharmacology. 2004;58:303-9. [36] Lin ZF, Wang CY, Shen L, Hsiao FY, Lin Wu FL. Statin Use and the Risk for Incident Diabetes Mellitus in Patients with Acute Coronary Syndrome after Percutaneous Coronary Intervention: A Population-Based Retrospective Cohort Study in Taiwan. Canadian journal of diabetes. 2016;40:264-9.

[37] Olotu BS, Shepherd MD, Novak S, Lawson KA, Wilson JP, Richards KM, et al. Use of Statins and the Risk of Incident Diabetes: A Retrospective Cohort Study. American journal of cardiovascular drugs : drugs, devices, and other interventions. 2016;16:377-90.

[38] Rha SW, Choi BG, Seo HS, Park SH, Park JY, Chen KY, et al. Impact of Statin Use on Development of New-Onset Diabetes Mellitus in Asian Population. The American journal of cardiology. 2016;117:382-7.

[39] van de Woestijne AP, van der Graaf Y, Westerink J, Nathoe HM, Visseren FL. Effect of statin therapy on incident type 2 diabetes mellitus in patients with clinically manifest vascular disease. The American journal of cardiology.

2015;115:441-6.

[40] Wang KL, Liu CJ, Chao TF, Huang CM, Wu CH, Chen SJ, et al. Statins, risk of diabetes, and implications on outcomes in the general population. Journal of the American College of Cardiology. 2012;60:1231-8.

[41] Coleman Cl, Reinhart K, Kluger J, White CM. The effect of statins on the development of new-onset type 2 diabetes: a meta-analysis of randomized controlled trials. Current medical research and opinion. 2008;24:1359-62.

[42] Navarese EP, Buffon A, Andreotti F, Kozinski M, Welton N, Fabiszak T, et al. Meta-analysis of impact of different types and doses of statins on new-onset diabetes mellitus. The American journal of cardiology. 2013;111:1123-30. [43] Schrom JR, Caraballo PJ, Castro MR, Simon GJ. Quantifying the effect of statin use in pre-diabetic phenotypes discovered through association rule mining. AMIA Annual Symposium proceedings / AMIA Symposium AMIA Symposium. 2013;2013:1249-57.

[44] Park JY, Rha SW, Choi B, Choi JW, Ryu SK, Kim S, et al. Impact of low dose atorvastatin on development of newonset diabetes mellitus in Asian population: Three-year clinical outcomes. International journal of cardiology. 2015;184:502-6.

[45] Corrao G, Ibrahim B, Nicotra F, Soranna D, Merlino L, Catapano AL, et al. Statins and the risk of diabetes: evidence from a large population-based cohort study. Diabetes care. 2014;37:2225-32.

[46] Arfe A, Corrao G. Tutorial: strategies addressing detection bias were reviewed and implemented for investigating the statins-diabetes association. Journal of clinical epidemiology. 2015;68:480-8.

[47] Swerdlow DI, Preiss D, Kuchenbaecker KB, Holmes MV, Engmann JE, Shah T, et al. HMG-coenzyme A reductase inhibition, type 2 diabetes, and bodyweight: evidence from genetic analysis and randomised trials. Lancet.

2015;385:351-61.

[48] Andersson C, Lyass A, Larson MG, Robins SJ, Vasan RS. Low-density-lipoprotein cholesterol concentrations and risk of incident diabetes: epidemiological and genetic insights from the Framingham Heart Study. Diabetologia.

2015;58:2774-80.

[49] Li N, van der Sijde MR, LifeLines Cohort Study G, Bakker SJ, Dullaart RP, van der Harst P, et al. Pleiotropic effects of lipid genes on plasma glucose, HbA1c, and HOMA-IR levels. Diabetes. 2014;63:3149-58.

[50] Fall T, Xie W, Poon W, Yaghootkar H, Magi R, Consortium G, et al. Using Genetic Variants to Assess the Relationship Between Circulating Lipids and Type 2 Diabetes. Diabetes. 2015;64:2676-84.

[51] Besseling J, Kastelein JJ, Defesche JC, Hutten BA, Hovingh GK. Association between familial hypercholesterolemia and prevalence of type 2 diabetes mellitus. Jama. 2015;313:1029-36.

[52] Brault M, Ray J, Gomez YH, Mantzoros CS, Daskalopoulou SS. Statin treatment and new-onset diabetes: a review of proposed mechanisms. Metabolism: clinical and experimental. 2014;63:735-45.

[53] Zhao W, Zhao SP. Different effects of statins on induction of diabetes mellitus: an experimental study. Drug design, development and therapy. 2015;9:6211-23.

[54] Nakata M, Nagasaka S, Kusaka I, Matsuoka H, Ishibashi S, Yada T. Effects of statins on the adipocyte maturation and expression of glucose transporter 4 (SLC2A4): implications in glycaemic control. Diabetologia. 2006;49:1881-92.

[55] Khan T, Hamilton MP, Mundy DI, Chua SC, Scherer PE. Impact of simvastatin on adipose tissue: pleiotropic effects in vivo. Endocrinology. 2009;150:5262-72. 
[56] McGuire TF, Xu XQ, Corey SJ, Romero GG, Sebti SM. Lovastatin disrupts early events in insulin signaling: a potential mechanism of lovastatin's anti-mitogenic activity. Biochemical and biophysical research communications. 1994;204:399406.

[57] Takaguri A, Satoh K, Itagaki M, Tokumitsu Y, Ichihara K. Effects of atorvastatin and pravastatin on signal transduction related to glucose uptake in 3T3L1 adipocytes. Journal of pharmacological sciences. 2008;107:80-9. [58] Brunham LR, Kruit JK, Hayden MR, Verchere CB. Cholesterol in beta-cell dysfunction: the emerging connection between HDL cholesterol and type 2 diabetes. Current diabetes reports. 2010;10:55-60.

[59] Brunham LR, Kruit JK, Pape TD, Timmins JM, Reuwer AQ, Vasanji Z, et al. Beta-cell ABCA1 influences insulin secretion, glucose homeostasis and response to thiazolidinedione treatment. Nature medicine. 2007;13:340-7. [60] Kruit JK, Kremer PH, Dai L, Tang R, Ruddle P, de Haan W, et al. Cholesterol efflux via ATP-binding cassette transporter $A 1$ ( $A B C A 1$ ) and cholesterol uptake via the LDL receptor influences cholesterol-induced impairment of beta cell function in mice. Diabetologia. 2010;53:1110-9.

[61] Collins R, Reith C, Emberson J, Armitage J, Baigent C, Blackwell L, et al. Interpretation of the evidence for the efficacy and safety of statin therapy. Lancet. 2016. 
Table 1 Selected characteristics of 20 observational studies included in the meta-analysis

\begin{tabular}{|c|c|c|c|c|c|c|c|}
\hline $\begin{array}{l}\text { First author } \\
\text { (Year) }\end{array}$ & Design & $\begin{array}{l}\text { Study } \\
\text { duration } \\
\text { (year) }\end{array}$ & $\begin{array}{l}\text { NOD } \\
\text { definition }\end{array}$ & $\begin{array}{l}\text { Mean } \\
\text { age } \\
\text { (year) }\end{array}$ & Exposure & $\begin{array}{l}\text { OR/RR/HR } \\
(95 \% \mathrm{Cl})\end{array}$ & Adjustment \\
\hline Jick SS (2004) & $\begin{array}{l}\text { Nested } \\
\text { case- } \\
\text { control }\end{array}$ & 11 & $\begin{array}{l}\text { diagnosis } \\
\text { AND drugs }\end{array}$ & 59.2 & $\begin{array}{l}\text { Any statin } \\
\text { Pravastatin } \\
\text { Simvastatin }\end{array}$ & $\begin{array}{l}1.1(0.8-1.4) \\
0.7(0.4-1.2) \\
1.0(0.7-1.3)\end{array}$ & $\begin{array}{l}\text { Body mass index, hypertension, steroid use, smoking and } \\
\text { the number of GP visits within } 3 \text { years preceding the index } \\
\text { date }\end{array}$ \\
\hline $\begin{array}{l}\text { Culver A } \\
(2012)\end{array}$ & Cohort & 9 & $\begin{array}{l}\text { self- } \\
\text { reported }\end{array}$ & 63.2 & $\begin{array}{l}\text { Any statin } \\
\text { Simvastatin } \\
\text { Fluvastatin } \\
\text { Atorvastatin } \\
\text { Pravastatin }\end{array}$ & $\begin{array}{l}1.48(1.38-1.59) \\
1.41(1.25-1.61) \\
1.61(1.35-1.92) \\
1.61(1.26-2.06) \\
1.63(1.43-1.87)\end{array}$ & $\begin{array}{l}\text { Age, race/ethnicity, education, cigarette smoking, BMI, } \\
\text { physical activity, alcohol intake, energy intake, family } \\
\text { history of diabetes, hormone therapy use, study arms, and } \\
\text { self-report of cardiovascular disease at baseline }\end{array}$ \\
\hline $\begin{array}{l}\text { Danaei G } \\
(2012)\end{array}$ & Cohort & 9 & $\begin{array}{l}\text { diagnosis } \\
\text { OR drugs }\end{array}$ & 63.2 & $\begin{array}{l}\text { Any statin } \\
\text { Simvastatin } \\
\text { Atorvastatin } \\
\text { Pravastatin } \\
\text { Rosuvastatin } \\
\text { Fluvastatin }\end{array}$ & $\begin{array}{l}1.14(1.09-1.19) \\
1.14(1.09-1.20) \\
1.22(1.12-1.32) \\
1.01(0.84-1.21) \\
1.11(0.89-1.38) \\
1.02(0.69-1.50)\end{array}$ & $\begin{array}{l}\text { Gender, townsend deprivation score, age, LDL cholesterol, } \\
\text { HDL cholesterol, BMI, systolic blood pressure, alcohol use, } \\
\text { doctor visits, referrals, hospitalizations, alcoholism, } \\
\text { smoking prevalence, hypertension, antihypertensive use, } \\
\text { NSAIDs use, aspirin use, other lipid-lowering drugs use, b- } \\
\text { Blockers use, hormone replacement therapy, chronic } \\
\text { obstructive pulmonary disease, oral steroids use, inhaled } \\
\text { steroids use, atrial fibrillation, depression, antidepressant } \\
\text { use, hypothyroidism, osteoporosis, history of transplant, } \\
\text { immunosuppression therapy, psoriasis, rheumatoid } \\
\text { arthritis, chemotherapy, radiotherapy, chronic pancreatitis }\end{array}$ \\
\hline $\begin{array}{l}\text { Wang KL } \\
\text { (2012) }\end{array}$ & Cohort & 8 & $\begin{array}{l}\text { diagnosis } \\
\text { AND drugs }\end{array}$ & 63.0 & Any statin & $1.15(1.08-1.22)$ & Unadjusted \\
\hline $\begin{array}{l}\text { Chen CW } \\
(2013)\end{array}$ & $\begin{array}{l}\text { Case- } \\
\text { control }\end{array}$ & 2 & diagnosis & 61.3 & $\begin{array}{l}\text { Atorvastatin } \\
\text { Rosuvastatin } \\
\text { Simvastatin } \\
\text { Pravastatin }\end{array}$ & $\begin{array}{l}2.80(1.74-4.49) \\
4.69(2.78-7.92) \\
4.09(2.52-6.64) \\
3.41(1.66-7.04)\end{array}$ & $\begin{array}{l}\text { Gender, hypertension, coronary heart disease, diabetes, } \\
\text { hyperlipidemia, atrial fibrillation, chronic kidney disease, } \\
\text { obesity, peripheral arterial disease, non-statin lipid lowering } \\
\text { medications, aspirin, angiotensin-converting enzyme } \\
\text { inhibitors, triglyceride-lowering medications, hormone } \\
\text { therapy, socioeconomic status, geographic region and } \\
\text { urbanization level of residence }\end{array}$ \\
\hline $\begin{array}{l}\text { Currie O } \\
(2013)\end{array}$ & Cohort & 6 & drugs & NA & Any statin & $3.31(2.56-4.30)$ & Age, sex, and ethnicity \\
\hline
\end{tabular}




\begin{tabular}{|c|c|c|c|c|c|c|c|}
\hline Izzo R (2013) & Cohort & 4.7 & $\begin{array}{l}\text { biochemical } \\
\text { s AND } \\
\text { (diagnosis } \\
\text { OR drugs) }\end{array}$ & 58.6 & Any statin & $1.03(0.79-1.35)$ & $\begin{array}{l}\text { Age, gender, use of statins before diagnosis of diabetes, } \\
\text { duration of hypertension and baseline parameters }\end{array}$ \\
\hline $\begin{array}{l}\text { Zaharan } \\
\mathrm{NL}(2013)\end{array}$ & Cohort & $6 / 9$ & drugs & NA & $\begin{array}{l}\text { Any statin } \\
\text { Atorvastatin } \\
\text { Pravastatin } \\
\text { Rosuvastatin } \\
\text { Simvastatin } \\
\text { Fluvastatin }\end{array}$ & $\begin{array}{l}1.20(1.17-1.23) \\
1.25(1.21-1.28) \\
1.02(0.98-1.06) \\
1.42(1.33-1.52) \\
1.14(1.06-1.23) \\
1.04(0.91-1.18)\end{array}$ & $\begin{array}{l}\text { Gender, age groups, prescriptions of oral corticosteroids, } \\
\text { antipsychotics, antihypertensive drugs, medications for } \\
\text { ischaemic heart disease, anti-obesity and other lipid } \\
\text { modifying agents. }\end{array}$ \\
\hline $\begin{array}{l}\text { Bhattacharya } \\
\text { R (2014) }\end{array}$ & Cohort & 2 & diagnosis & NA & Any statin & $1.62(1.25-2.09)$ & $\begin{array}{l}\text { Antidepressants-statins use; presence of depression; life } \\
\text { style risk factors - BMI categories, lack of physical activity, } \\
\text { smoking status, age groups, gender; race/ethnicity; poverty } \\
\text { status, insurance status }\end{array}$ \\
\hline $\begin{array}{l}\text { Cederberg H } \\
\text { (2014) }\end{array}$ & Cohort & 5.9 & $\begin{array}{l}\text { biochemical } \\
\text { s OR } \\
\text { diagnosis } \\
\text { OR drugs }\end{array}$ & 57.1 & Any statin & $1.46(1.22-1.74)$ & $\begin{array}{l}\text { Age, BMI, waist circumference, physical activity, smoking, } \\
\text { alcohol intake, family history of diabetes and beta-blocker } \\
\text { and diuretic treatment }\end{array}$ \\
\hline $\begin{array}{l}\text { Macedo AF } \\
(2014)\end{array}$ & Cohort & 20 & diagnosis & 62.3 & Any statin & $1.57(1.54-1.59)$ & $\begin{array}{l}\text { Adjusted for age, gender, propensity score, post index date } \\
\text { diagnosis of hepatic disease and family history of diabetes }\end{array}$ \\
\hline $\begin{array}{l}\text { Lichtenstein } \\
\text { KA (2015) }\end{array}$ & Cohort & 10 & $\begin{array}{l}\text { biochemical } \\
\text { s OR drugs }\end{array}$ & 40.0 & Any statin & $1.14(1.02-1.27)$ & $\begin{array}{l}\text { Age, sex, race/ethnicity, exposure to antiretroviral therapy, } \\
\text { prevalent hepatitis C, BMI, and cumulative use of protease } \\
\text { inhibitors }\end{array}$ \\
\hline Mansi I (2015) & Cohort & 10 & diagnosis & 53.0 & Any statin & $1.87(1.67-2.01)$ & $\begin{array}{l}\text { Propensity score (age, gender, smoking, alcohol-related } \\
\text { disorders, substance-related disorders, charlson } \\
\text { comorbidity score, overweight/obese, hypertension, acute } \\
\text { kidney injury, asthma, gastrointestinal hemorrhage, } \\
\text { gastritis/duodenitis, nonspecific chest pain, heart disease } \\
\text { not otherwise specified, osteoarthritis, arthropathy, and } \\
\text { back disorder, sprains, strains, and trauma-related joint } \\
\text { disorders, fracture of bone, osteoporosis, rehabilitation } \\
\text { care, fitting of prostheses, and adjustment of devices, } \\
\text { number of inpatient admissions, number of outpatient } \\
\text { medical encounters, number of encounters for } \\
\text { immunization, receive immunization and screening for }\end{array}$ \\
\hline
\end{tabular}




\begin{tabular}{|c|c|c|c|c|c|c|c|}
\hline & & & & & & & $\begin{array}{l}\text { infectious disease, beta-blocker, diuretic, ACE-Is/ARBs, } \\
\text { calcium channel blocker, proton pump inhibitors, aspirin, } \\
\text { NSAIDs, bisphosphonates, sedatives, SSRI, antipsychotic, } \\
\text { tricyclic anti-depressants, systemic corticosteroids, } \\
\text { hormone replacement therapy, testosterone, cytochrome } \\
\text { p450, non-statin lipid lowering drugs, oral hypoglycemic, } \\
\text { antiplatelet agents (other than aspirin), warfarin) }\end{array}$ \\
\hline $\begin{array}{l}\text { Radford NB } \\
(2015)\end{array}$ & Cohort & 3 & $\begin{array}{l}\text { biochemical } \\
\text { s OR drugs } \\
\text { OR self- } \\
\text { reported }\end{array}$ & 48.2 & Any statin & $2.04(1.30-3.22)$ & $\begin{array}{l}\text { Statin use at visit } 2, \text { age, gender, chronic renal failure, and } \\
\text { metabolic syndrome at index visit }\end{array}$ \\
\hline $\begin{array}{l}\text { van de } \\
\text { Woestijne AP } \\
(2015)\end{array}$ & Cohort & 15 & $\begin{array}{l}\text { self- } \\
\text { reported } \\
\text { (with cross- } \\
\text { validation) }\end{array}$ & 59.0 & Any statin & $1.66(1.14-2.42)$ & $\begin{array}{l}\text { Age, gender and propensity score (age, sex, localisation of } \\
\text { vascular disease, body mass index, HDL-cholesterol, } \\
\text { plasma triglycerides, systolic blood pressure, plasma } \\
\text { glucose, platelet inhibitors, blood pressure lowering } \\
\text { medication, smoking, eGFR and time since inclusion) }\end{array}$ \\
\hline Calza L (2016) & Cohort & 5.2 & $\begin{array}{l}\text { biochemical } \\
\text { s OR drugs }\end{array}$ & 44.5 & Any statins & $1.09(0.76-1.49)$ & $\begin{array}{l}\text { Age, sex, race, chronic hepatitis } \mathrm{C} \text {, body mass index, } \\
\text { fasting serum concentration of triglycerides, cumulative } \\
\text { exposure to combination antiretroviral therapy (cART) and } \\
\text { cumulative exposure to specific antiretroviral agents }\end{array}$ \\
\hline $\begin{array}{l}\text { Castro MR } \\
(2016)\end{array}$ & Cohort & 6 & diagnosis & 55.7 & Any statins & $1.19(1.05-1.35)$ & $\begin{array}{l}\text { Lipid panel (LDL, HDL, triglycerides), blood pressure, body } \\
\text { mass index, the use of hypertension drugs and } \\
\text { demographics (age and gender) }\end{array}$ \\
\hline \multirow{6}{*}{ Lin ZF (2016) } & \multirow{6}{*}{ Cohort } & \multirow{6}{*}{3.1} & \multirow{6}{*}{ diagnosis } & \multirow{6}{*}{65.4} & \multirow{6}{*}{$\begin{array}{l}\text { Any statin } \\
\text { Atorvastatin } \\
\text { Pravastatin } \\
\text { Rosuvastatin } \\
\text { Simvastatin } \\
\text { Fluvastatin }\end{array}$} & $1.27(1.14-1.41)$ & \multirow{6}{*}{$\begin{array}{l}\text { Age, sex, various comorbidities (ischemic heart disease, } \\
\text { cerebrovascular disease, heart failure, hypertension, renal } \\
\text { disease, hyperlipidemia, liver disease and peripheral } \\
\text { vascular disease) and comedication }\end{array}$} \\
\hline & & & & & & $1.30(1.13-1.50)$ & \\
\hline & & & & & & $1.71(1.12-2.60)$ & \\
\hline & & & & & & $1.42(1.23-1.64)$ & \\
\hline & & & & & & $1.60(1.10-2.32)$ & \\
\hline & & & & & & $1.38(1.07-1.80)$ & \\
\hline $\begin{array}{l}\text { Olotu BS } \\
(2016)\end{array}$ & Cohort & 1.3 & diagnosis & 46.3 & $\begin{array}{l}\text { Any statin } \\
\text { Atorvastatin } \\
\text { Pravastatin } \\
\text { Rosuvastatin } \\
\text { Simvastatin } \\
\text { Fluvastatin }\end{array}$ & $\begin{array}{l}2.07(1.77-2.42) \\
1.95(1.62-2.35) \\
1.40(1.04-1.87) \\
1.75(1.19-2.56) \\
1.79(1.43-2.24) \\
1.95(1.28-2.96)\end{array}$ & $\begin{array}{l}\text { Age, sex, hyperlipidemia, obesity, hypertension, use of } \\
\text { diabetogenic medications, and Charlson Comorbidity Index } \\
\text { score }\end{array}$ \\
\hline
\end{tabular}




\begin{tabular}{|c|c|c|c|c|c|c|c|}
\hline $\begin{array}{l}\text { Rha SW } \\
(2016)\end{array}$ & Cohort & 3 & $\begin{array}{l}\text { biochemical } \\
\text { s OR drugs }\end{array}$ & 60.2 & $\begin{array}{l}\text { Any statin } \\
\text { Atorvastatin } \\
\text { Pravastatin } \\
\text { Rosuvastatin } \\
\text { Simvastatin } \\
\text { Fluvastatin }\end{array}$ & $\begin{array}{l}1.99(1.36-2.92) \\
2.09(1.27-3.44) \\
2.88(1.50-5.55) \\
2.13(1.04-4.38) \\
0.99(0.49-2.02) \\
2.54(1.03-6.21)\end{array}$ & $\begin{array}{l}\mathrm{M} \text { ale gender, age, history of risk (hypertension, coronary } \\
\text { artery disease, coronary spasm, dyslipidemia, angiotensin } \\
\text { receptor blockers, angiotensin-converting enzyme } \\
\text { inhibitors, calcium channel blockers, b blockers, diuretics, } \\
\text { nitrates, and statins }\end{array}$ \\
\hline
\end{tabular}


Table 2 Stratified analyses based on duration of follow-up, on geographic areas and propensity score matching

\begin{tabular}{|c|c|c|c|c|c|c|}
\hline Strata & $\mathrm{N}$ & $\bar{Q}$ & Q p-value & $\overline{1^{2}}$ & RR (95\%Cl) & $p$-value \\
\hline Overall & 19 & 611.89 & $<0.0001$ & 0.971 & $1.44(1.31-1.58)$ & \\
\hline \multicolumn{7}{|c|}{ Lenght of follow-up } \\
\hline$<7.2$ years & 10 & 88.845 & $<0.0001$ & 0.899 & $1.58(1.3-1.94)$ & \multirow{2}{*}{0.173} \\
\hline$\geq 7.2$ years & 9 & 522.19 & $<0.0001$ & 0.985 & $1.34(1.18-1.52)$ & \\
\hline \multicolumn{7}{|l|}{ Country } \\
\hline Asia & 4 & 11.723 & 0.0084 & 0.744 & $1.32(1.12-1.56)$ & \multirow{4}{*}{$<0.0001$} \\
\hline Europe & 8 & 433.93 & $<0.0001$ & 0.984 & $1.27(1.09-1.47)$ & \\
\hline USA & 7 & 77.404 & $<0.0001$ & 0.923 & $1.55(1.3-1.85)$ & \\
\hline NZL & 1 & - & - & - & $3.31(2.55-4.29)$ & \\
\hline \multicolumn{7}{|c|}{$\begin{array}{l}\text { PS matching } \\
\text { (cohort studies only) }\end{array}$} \\
\hline No & 13 & 159.51 & $<0.0001$ & 0.925 & $1.43(1.29-1.59)$ & \multirow{2}{*}{0.195} \\
\hline Yes & 6 & 30.895 & $<0.0001$ & 0.871 & $1.61(1.39-1.86)$ & \\
\hline
\end{tabular}

$\mathrm{N}$ : number of studies included in each stratum, $\mathrm{Q}$ and $\mathrm{Q} p$-value: value of the $\mathrm{Q}$ statistics and corresponding $\mathrm{p}$-value of the test, $\mathrm{I}^{2}$ : value of the $\mathrm{I}^{2}$ index, $\mathrm{RR}(95 \% \mathrm{Cl})$ : value of the stratum-specific relative risk estimate and corresponding 95\% confidence interval, $p$-value: $p$-value of the test for between-strata difference in the estimates. 


\section{Fure(s)}

Click here to download high resolution image
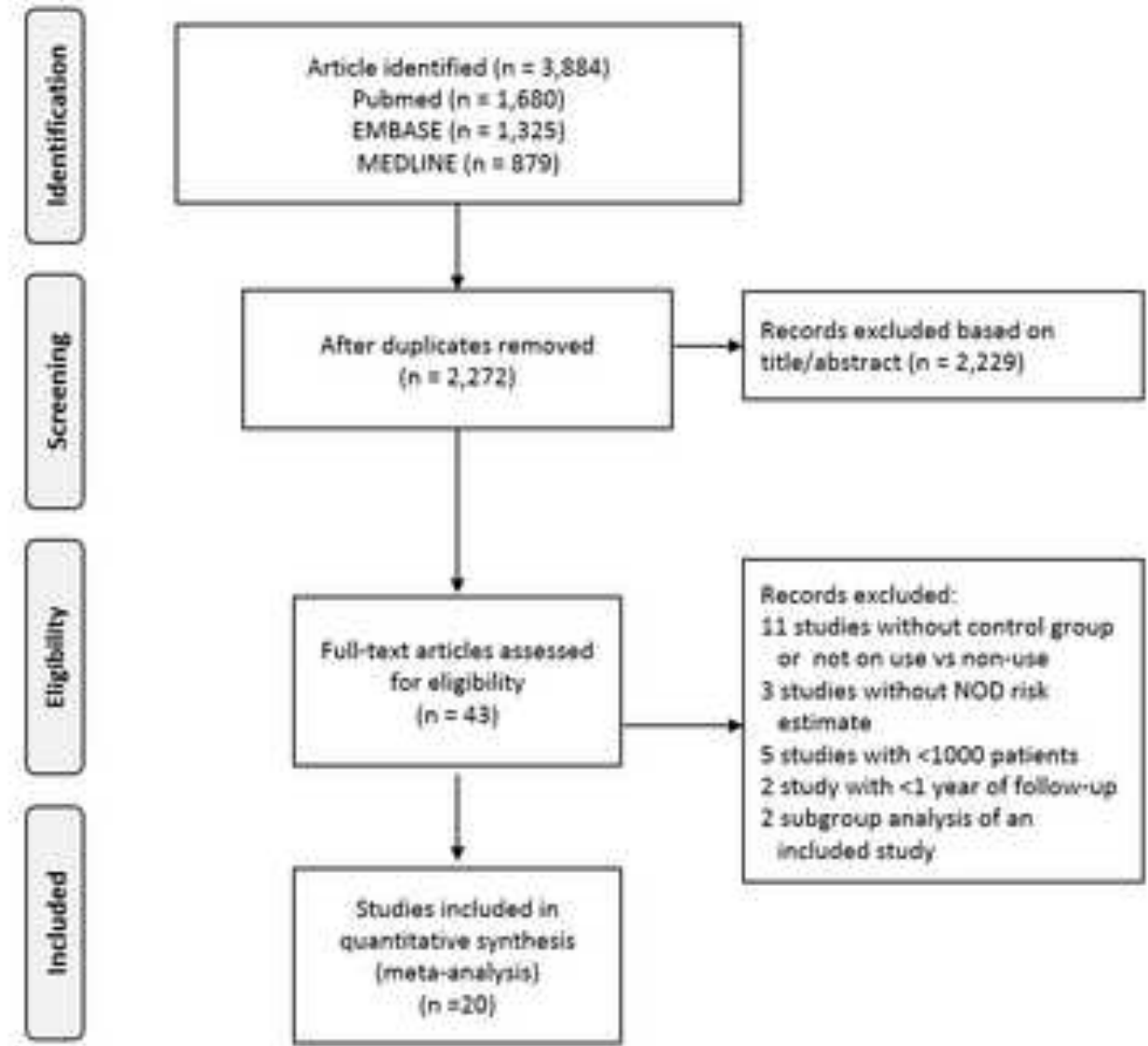

Studies included in

quantitative synthesis [meta-analvis) $(n=20)$ 


\section{Forest plot - Any statin}

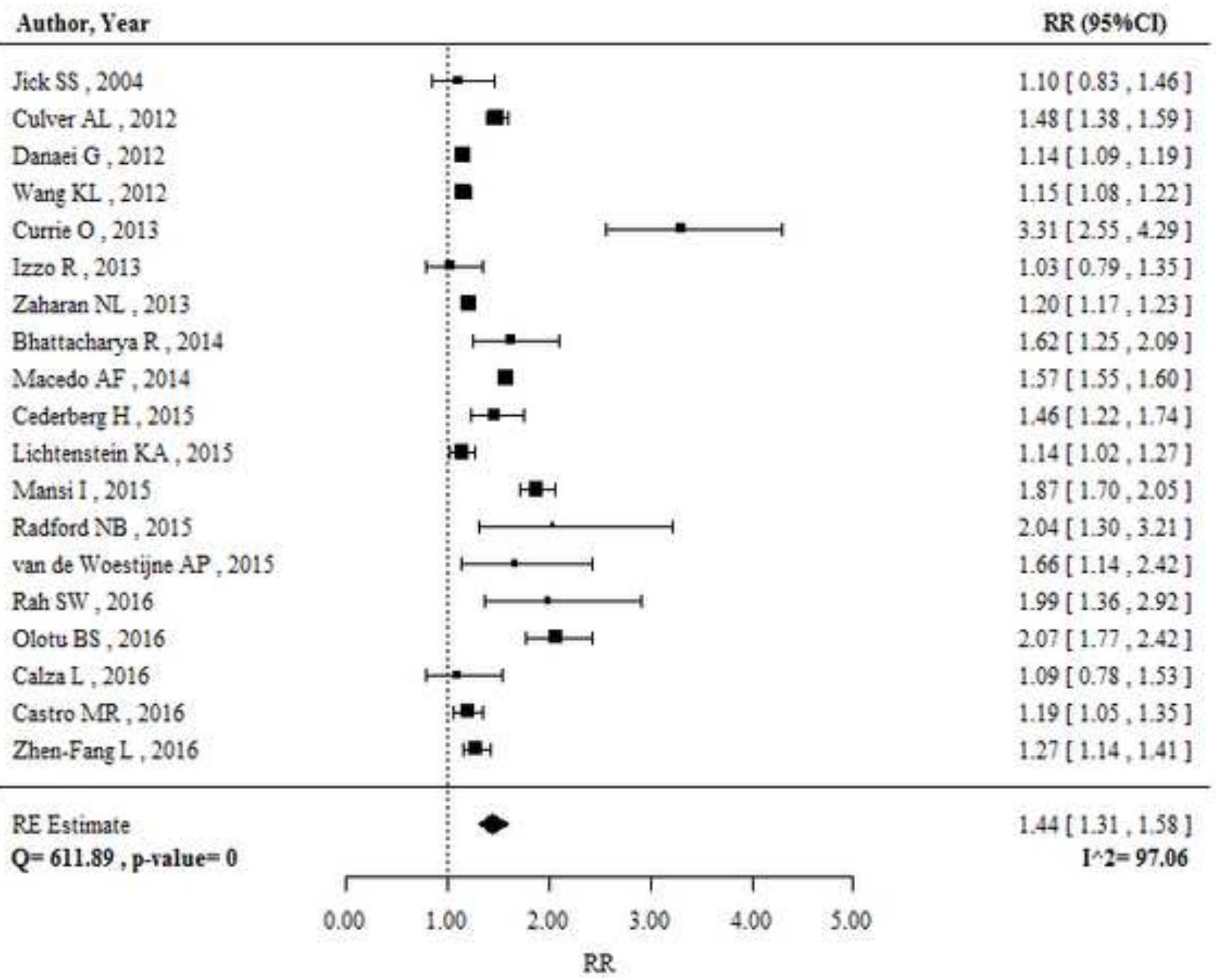


Forest plat - Acenastaria

\begin{tabular}{|c|c|c|}
\hline Antar.Ver & & kxounto \\
\hline Onest,2wi & $\longrightarrow$ & $\operatorname{sen} 12 x, 450 ;$ \\
\hline conestivis & $\omega$ & Let13:at \\
\hline 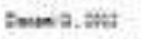 & $=$ & 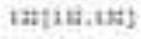 \\
\hline Tomanin, wis & $=$ & vat19,4:3\} \\
\hline $\tan r=2001$ & $\longrightarrow$ & $2 W \operatorname{Lag}-1 \mathrm{Al}$ \\
\hline 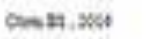 & $\cdots$ & 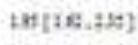 \\
\hline Destagt, ats & $\rightarrow$ & 10!1日, 180 ; \\
\hline \multirow[t]{2}{*}{ gytats: } & - & 14rasiatid \\
\hline & 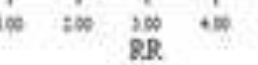 & \\
\hline
\end{tabular}

Fotest plet - Prasastaria

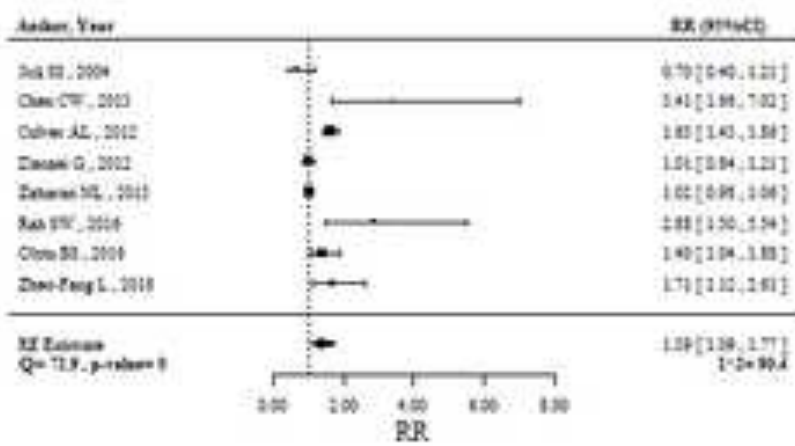

Ferest plot - Rosuratatia

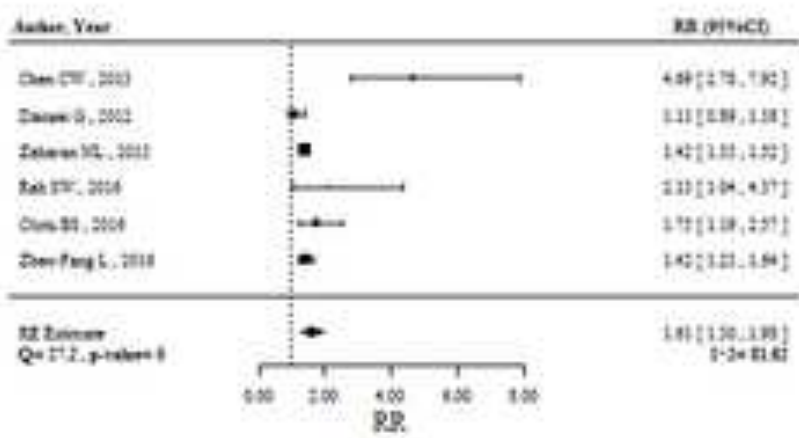

Fotest plet - Fluvastatia

\begin{tabular}{|c|c|c|}
\hline 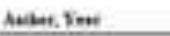 & & searace \\
\hline Alentialts & * & +40;:H, $+\mathrm{k}\}$ \\
\hline Dewo 0, sted & + & 14tom,1.57 \\
\hline 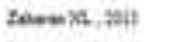 & 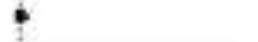 & 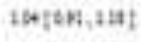 \\
\hline 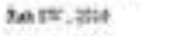 & $\longrightarrow$ & $520[1+3.68\}$ \\
\hline Anst 360 & 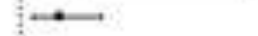 & Letiatan] \\
\hline Demtentitin & - & 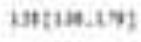 \\
\hline 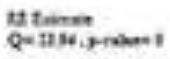 & - & 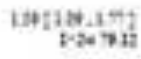 \\
\hline & *se $\mathrm{RR}^{*}$ is & \\
\hline
\end{tabular}

Forest plat - Simvastatia

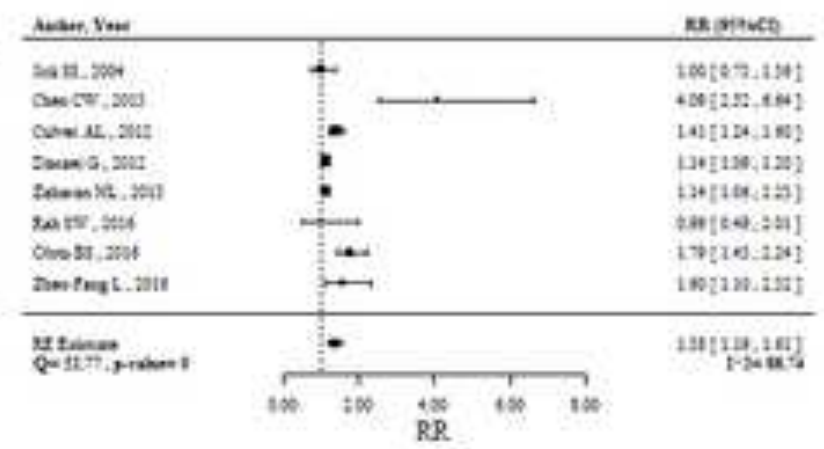

